SECTION 29. Literature. Folklore. Translation Studies.

Marunevich Oksana Viktorovna

Ph.D. in Linguistics,

Associate Professor of Rostov State Transport University

\title{
THE NAIVE VIEWS OF EVIL SPIRITS AS FOREIGNERS IN ENGLISH AND RUSSIAN FOLKLORE IN XVII-XIX CENTURIES
}

The article deals with the folklore and mythological interpretation of a particular ethnic group as a representative of the evil forces. It analyzes the medieval and modern Russian and English legends and beliefs, proverbs, sayings and dialect expressions that reflect a range of naive views about ethnic, cultural and faith dissimilarity between the given and other nations.

Key words: foreigner, evil forces, naïve views, Jew

\section{НАИВНЫЕ ПРЕДСТАВЛЕНИЯ О НЕЧИСТОМ ДУХЕ КАК ЭТНИЧЕСКИ ЧУЖОМ В АНГЛИЙСКОМ И РУССКОМ ФОЛЬКЛОРЕ ХVII-XIX ВВ.}

В статье рассматривается фольклорно-мифологическая трактовка представителя иного этноса как нечистой силь. Анализируются средневековые и современные русские и английские легенды и поверья, паремии и диалектные выражения, отражающие цельй комплекс наивных взглядов на этническую, конфессиональную и культурную несхожесть своего и чужого народа.

Ключевые слова: этнически чужой, нечистая сила, наивное сознание, uудей.

Для каждого народа характерно свое собственное видение окружающего мира. Данная мысль легла в основу концепции этнической картины мира, сформулированной Р. Рэдфилдом. Каждый народ также обладает своей собственной исторической памятью, которая является маркером принадлежности к определенному этносу, осознанием своего отличия и сходства при сравнении с другими этносами.

Согласно исследованиям философа-космолога М. Элиаде «память об истинном и историческом событии или подлинном персонаже хранится в народе не более двух или трѐх столетий», затем событие ассимилируется с категорией мифических действий (борьба с гигантами в английском фольклоре, враги-великаны в сказаниях русского севера и т.д.). Продолжая мысль М. Элиаде, мы можем предположить, что со временем и мифическая память уходит в не бытиѐ и остаются лишь отдельные фрагменты, каких-то неясных событий происходивших в далѐком прошлом и обросших невероятными иносказаниями. Перед нами предстаѐт область уже не мифа, а гипотетических фактов. Они представляют уже 
времена не мифической памяти дошедшей до нас в форме мифических сказаний, былин, легенд или сказок, имеющих в своей основе реальные события, обросшие невероятными описаниями в силу удалѐнности во времени и в соответствии с этим их приукрашивания. Это времена когда человечество утратило свою историческую память о реальности происходивших когда-то событий, в соответствии с чем произошла их глобализация и последующая консервация в наивном сознании этноса. Таковы, например, устойчивые представления европейского крестьянства о тождестве нечистой силы - черта, дьявола с представителями других наций:

Then Jos's native servant arose $<\ldots>$ then the maidservants got up, and meeting the dark man in the passages, shrieked, and mistook him for the devil (Thackeray W.M. Vanity Fair).

- Не знаешь, не видишь разве, что за человек? Ты только на рожу-то его погляди, на ухмылки его анафемские полюбуйся, да на весь его обычай поганый, на хрюк его свинячий, на глум-то его скаредный обрати внимание, сделай милость. Тем только от черного и отличается, что хвоста да копыт нет < ..>, сущий испанец (Сологуб Ф.К. Мелкий бес).

Подобные представления зафиксированы и в паремиологическом фонде русского языка: Бог создал Адама, а черт - молдавана; Зырянин рыж от бога, татарин рыж от черта; Первого черемиса леший родил, Жиды да черти одной шерсти; Бесы и жиды - дети сатаны [10], Бог сотворив цапа, а чорт - качапа [14, с. 257].

В значительной степени это объясняется тем, что в народных легендах черт оказывается «прародителем» нации. Согласно украинской легенде, черт решил сотворить кого-нибудь, подобного себе. С этой целью он накидал в котел смолы и разнообразного колдовского зелья и стал варить. Первым он выварил хохла. Решив, что «недоварил», черт через некоторое время выловил из котла ляха-поляка, следующим оказался немец, потом татарин. Кроме того, русские называли украинцев чертовыми головами. По легенде, однажды Господь и Святой Петр спустились с небес на землю и услышали в камышах страшный шум: там дрались черт с хохлом. Святой Петр «помирил» дерущихся, оторвав им головы. Когда Господь пристыдил его за столь жестокие меры, Петр приставил головы обратно, но при этом перепутал их: таким образом, у хохла оказалась чертова голова. По легенде из Галиции, цыгане - это потомки женщины и черта, а по гуцульским поверьям от женщины и черта произошли влахи.

На тождество дьявола и этнически чужого также указывает существование схожих сказаний о том, как в Ивановскую ночь мужик нашел цветок папоротника, способный открыть его владельцу все клады, однако у незадачливого мужика по одной из версий цветок был украден старым жидом, а по второй - нечистым духом. 
Следует отметить, что для русского наивного сознания традиционно отождествление черте и иудеев (жидов): Около жида потрѐшься бесовского наберѐшься. Служба жиду - на радость бесу. На жида и сам Бог не угодит. Последняя пословица подчеркивает не только, что евреям трудно в чем-то угодить, но и на их «особое», пренебрежительное отношение к Богу и религии: Бог и жида хранит, а жид Его бранит. От жида и Бог много раз плакал. Что Богу угодно, то жиду непригодно. Что Богу грешно, то жиду смешно. Чтут жиды жидовского бога Мамона.

Мамона - один из богов языческого пантеона, являвшийся покровителем богатых людей. В христианской традиции ассоциировался с дьяволом. В апокрифах Мамона является одним из представителей «силы бесовской», противостоящей Богу и ангелам. Данный образ возник вследствие народного переосмысления евангельского образа мамоны (божества богатства). В связи с этим упоминание о Мамоне беззаконном, мамоне насыльном и нахожем - опасных демонических существах встречается в заговорах и историко-литературных памятниках. Так, в «Молитве Архистратига Михаила от у скопу» (конец XIX в.) говорится о Мамоне - бесе проклятом. Кроме того служение Мамоне искони противопоставлялось служению Христу: «Работати Мамоне неправедному» [12, с. 322-323]. Поэтому в русских пословицах указывается на связь евреев с нечистой силой: Бесь и жиды - дети сатаны; У жида и бес в няньках служит. С жидом знаться - с бесом связаться. Не надо и беса, коли жид здеся. Нет беса в доме - прими жида. Жид в хату - ангель из хаты. Жид, как бес - никогда не покается. Жид не силой берѐт, а искушением.

В средние века регулярно циркулировали слухи о грядущем рождении Антихриста, причем его матерью всегда была иудейка: In the year 1599 ... Antichrist had been born at Babylon and that already the Jews of that part were hurrying to receive and recognize him as their Messiah [3, p. 232-233]. In 1600 the Man of Sin had been born in the neighbourhood of Paris of a Jewess named Blanchefleur who had conceived by Satan [3, p. 234]. A согласно средневековым мусульманским поверьям сын Сатаны завоюет мир во главе армии из 40000 иудеев. Даже в Евангелии от Иоанна в своей обличительной речи Иисус называет евреев детьми дьявола: вb́́ оти á [ва́mего] діа́вола есте́, и по́хоти отйа́ ва́шего хо́mете твори́ти: о́нъ человъкоубійца бъ искони́, и во и́стинг не стойть [11, 8: 44].

В Колымском наречии жидами называют лесных чертей [9, с. 51]. Интересно также, что в орловском говоре жид обозначает воробья [13, с. 118], а в Ланкашире бытует пословица - A spink and a sparrow are the devil's bow and arrow [5, p. 187]. На Украине также прослеживается связь данной триады жид - черт - воробей, т.к. воробьи зовутся чортово насіння. Более того, крестьяне верят, что воробьи, подобно жидам и чертям, не любят 
сала, поэтому тот, кто хочет отогнать воробьев от посева, должен при сеянии мазать руки освященным салом [8].

Литовская пословица гласит: Чужим духом всегда воняет. Аналогичная русская пословица утверждает: Каков жид, такова и его вонь. Согласно широко распространенному в Европе в Средние века предрассудку, евреи источают отчетливый и неприятный запах, который они получили в наказание за распятие Иисуса. Первым же эпитет «зловонные» евреям дал римский император Марк Аврелий: «Марк Аврелий ... был в досаде от зловонных и часто бунтующих иудеев» $[1, \mathrm{p}$, 316]. По понятию средневекового человека, святые духи благоухают удивительным и приятным запахом, в то время как злые духи и Сатана источают зловоние. Смрад - отличительный признак черта: образ распадающейся плоти свидетельствует о дьявольских кознях. Эта тема часто возникает и в демонологической литературе, и в художественной прозе. Так, в Польше встречается представление о водяном в облике еврея: быличка рассказывает, как рыбак выловил из реки Нарев водяного маленького еврея в ермолке и халате, который что-то бормотал поеврейски. Водяной разорвал сеть и выскочил в воду, оставив после себя запах серы [2]. Таким образом, в народном представлении специфический «запах» является одним из элементов инфернальности, что также сближает нечистую силу с этнически чужим.

Что касается английского языка, то даже само эвфемистическое имя дьявола - Old Nick этимологически восходит к иностранцу. Согласно Oxford English Dictionary, Nick - это дериват имени Niccolo известного итальянского политического деятеля Никколо Макиавелли (1469-1527). По мысли американского историка П. Стретерна, Макиавелли и зло в сознании большинства людей являются практически синонимами [7]. А по широко распространенному мнению представителей церкви того периода автором самой известной работы мыслителя "Государь" был сам дьявол, поэтому в скором времени его стали отождествлять с дьяволом буквально. Тридцать лет спустя после его смерти, его имя было известным в Англии. A к концу XVI в. это имя было знакомо широкому кругу публики, У. Шекспир использовал его в комедии "Merry wives of Windsor": Am I politic? am I subtle? am I a Machiavel? (Shakespeare W. Merry wives of Windsor).

Связь дьявола с именем Nick (Michael) также прослеживается в ряде поверий, существующих в графствах Англии: On Old Michaelmas Day the Devil throws his club over the bramble bushes as he marches over the land, making the blackberries unfit for eating. No Sussex person ever picked the berries after October 11th. The odd Sussex saying 'as black as the Devil's nutting bag' is associated with the superstition that it is unwise to gather nuts in autumn on a Sunday because that is when Old Nick is himself out nutting [6]. При этом традиционное место жительства нечистой силы - ад также 
ассоциируется с иными странами, чаще всего соседними: Финляндия чертова сторонушка [10], If anyone doubt of purgatory let him go to Scotland and his doubt will be dispelled [3, p. 327]. В среде немецкого крестьянства вплоть до середины XIX в. бытовало поверье, что Англия - это еще одно слово для обозначения потустороннего мира, мира мертвых, что также нашло отражение в языке: How the bells are ringing in England! (выражение использовалось во время похоронной процессии), How my children are crying in England!, обычно говорила мать, тоскующая по умершим детям [5, p. 177]. В это же время, своя страна, край, графство мыслятся как единственно праведные: There are more saints in Cornwall than there are in the Heaven [4, p. 1], Славится Москва невестами, колоколами да калачами, Матушка Москва белокаменная, златоглавая, хлебосольная, православная, словоохотливая, В Москве сорок сороков иерквей.

Таким образом, черты, предписываемые представителям иных этносов наивным сознанием, в большинстве своем имеют мифологическую основу. Оценка инородцев как враждебных и опасных существ восходит к архаическим верованиям о том, что все пришедшие извне и не принадлежащие ближайшему сообществу люди являются представителями «иного» мира - «чужими» и обладают сверхъестественными свойствами. В фольклоре к «чужим» кроме инородцев заведомо относится нечистая сила.

\section{Литература}

1. Ammianus Marcellinus. Greek and Roman Authors on Jews and Judaism. T. 2. Moscow. 2000.

2. Baranowski B. W kregu upjorow i wilkolakow. Lodz, 1981.

3. Baring-Gould S. Curious Myths of the Middle Ages. London, 1877.

4. Courtney M. Cornish Feast and Folklore. Penzance, 1890.

5. Hardwick Ch. Traditions, Superstitions, and Folklore (chiefly Lancashire and the North of England). London, 1878.

6. Latham Ch. Some West Sussex Superstitions. London, 1878.

7. Strathern P. Machiavelli in 90 minutes. Chicago: Ivan R.Dee, 1998.

8. Белова О. Евреи и славяне. Народная магия в регионах этнокультурных контактов // ruthenia.ru

9. Богораз В.Г. Областной словарь колымского русского наречия //Сб. ОРЯС. СПб., 1909. Т. 68, № 4.

10. Даль В.И. Пословицы, поговорки и прибаутки русского народа: Сборник в 2-х т. СПб.: Литера, Виан, 1997.

11. Евангелие от Иоанна. М., 2006.

12. Мифологическая энциклопедия. М.: Книга и бизнес, 1998.

13. Словарь орловских говоров. Ярославль, 1989. Вып. 3.

14. Чубинский П.П. Труды этнографическо-статистической экспедиции в Западнорусский край. СПб., 1872. Т. 1. Легенды, загадки, пословицы, колдовство.

15. Элиаде М. Миф о вечном возвращении // Избранные работы. М., 1987. 